\title{
Meningkatkan Kemampuan Menulis Puisi Melalui Teknik Akrostik Dengan Memanfaatkan Lingkungan Sekolah Pada Siswa Kelas V SDN 1 Midang Tahun Ajaran 2018/2019
}

\section{Lindra Defita}

\begin{abstract}
Abstrak. Tujuan dalam penelitian menerapkan teknik akrostik dengan memanfaatkan lingkungan sekolah untuk meningkatkan kemampuan menulis puisi siswa kelas V SDN 1 Midang Lombok Barat. Metode dalam penelitian adalah Penelitian tindakan kelas. Hasil penelitian menunjukkan terjadi peningkatan dari siklus ke siklus, dilihat dari nilai rata-rata siswa dan ketuntasan klasikal berturut-turut dari siklus I dan II adalah 70,9 dengan persentase ketuntasan klasikal74\%; dan 75,4 dengan persentase ketuntasan klasikal 89\%, hal ini berarti penelitian tindakan kelas ini telah memenuhi indikator yang ingin dicapai. Dengan demikian penerapan Teknik Akrostik Dengan Memanfaatkan Lingkungan Sekolah dapat Meningkatkan Kemampuan Menulis Puisi Siswa Kelas V SDN I Midang Kecamatan Gunung Sari Lombok Barat Tahun Ajaran $2018 / 2019$.
\end{abstract}

Kata Kunci: Teknik Akrostik,Lingkungan Sekolah, Kemampuan Menulis Puisi.

\section{PENDAHULUAN}

Menulis adalah salah satu aspek keterampilan berbahasa yang dipelajari siswa dalam mata pelajaran Bahasa Indonesia di sekolah. Siswa diharapkan dapat menguasai ragam keterampilan menulis yang tercakup dalam Standar Kompetensi dan Kompetensi Dasar. Selain itu, keterampilan menulis merupakan keterampilan yang sangat penting ditekankan pengajarannya oleh guru kepada para siswanya karena menulis membutuhkan kemampuan yang khusus. Oleh sebab itu, perlu adanya latihan dan praktik yang teratur juga memerlukan waktu yang relatif lama dalam penguasaannya. Dengan demikian, keterampilan menulis merupakan keterampilan berbahasa yang cenderung sulit dan membutuhkan ketelitian dalam pembelajarannya.

Kurangnya kemampuan siswa pada pembelajaran Bahasa Indonesia terutama banyak ditemukan dalam belajar menulis puisi, hal ini terlihat dari hasil belajar menulis puisi selama ini. Berdasarkan observasi awal terhadap kelas $\mathrm{V}$ SDN I MIDANG menunjukkan kemampuan siswa dalam menulis puisi masih rendah yang terlihat pada nilai Bahasa Indonesia siswa masih kurang khususnya dalam hal kemampuan menulis puisi. Berdasarkan hasil tes awal kemampuan menulis puisi, diperoleh nilai rata-rata dari 35 orang siswa yaitu 59,9 dengan ketuntasan klasikal sebesar 40\%. Selain itu, siswa masih belum bisa menyusun kata-kata menjadi sebuah barisan puisi yang indah. Puisi yang baik adalah puisi yang isinya menggambarkan suasana penulis dan dengan menggunakan bahasa atau pun kata-kata yang indah sehingga puisi tampak lebih indah dan memiliki makna denotasi serta konotasi (Tarigan, 1984:62). Kemampuan siswa dalam menulis puisi yang berkaitan dengan pengalamannya dapat mengembangkan, meningkatkan dan berkemampuan menulis dengan menggunakan Bahasa Indonesia dengan baik dan benar. Bagi siswa yang kurang begitu terampil dalam menulis puisi dapat ditingkatkan dengan cara latihan menulis. Menurut Tarigan (2009;9), "keterampilan menulis itu tidak datang dengan sendirinya, menuntut latihan yang 
cukup dan teratur serta pendidikan yang berprogram."

Dalam perkembanganya pendidikan memiliki peran yang bersifat universal. Isnaini (2018) Pendidikan memainkan peranan penting dalam hidup dan kehidupan bermasyarakat. Perkembangan dunia pendidikan tinggi mempunyai dampak terhadap proses pendidikan (Isnaini, 2012).Teknik akrostik merupakan rangkaian kegiatan dalam belajar menulis puisi yang lebih terarah dan menyenangkan. Dalam pelaksanaan pembelajaran, siswa akan dipandu mulai dari tahap penggalian ide, penentuan ide, penulisan sampai pada tahap penyajian. Teknik akrostik ini juga membantu siswa dalam menulis puisi, karena puisi yang dibuat menggunakan pola huruf-huruf awal nama diri atau suatu hal. Dengan adanya pola ini, proses penulisan puisi menjadi lebih terarah. Berangkat dari latar belakang di atas dan mengingat pentingnya kemampuan menulis puisi bagi siswa, maka perlu diadakan penelitian yang berusaha mengetahui seberapa besar peningkatan pembelajaran menulis puisi melalui teknik akrostik dengan memanfaatkan lingkungan sekitar sekolah. Alasan itulah yang mendasari peneliti untuk mengadakan penelitian dengan judul "Meningkatkan Kemampuan Menulis Puisi Melalui Teknik Akrostik Dengan Memanfaatkan Lingkungan Sekolah Pada Siswa Kelas V SDN 1 MIDANG Tahun Ajaran 2018/2019."

\section{METODE PENELITIAN}

Penelitian ini telah dilaksanakan di kelas V SDN I MIDANG, Desa Midang, kecamatan Gunungsari, Kabupaten Lombok Barat. Jenis penelitian ini adalah Penelitian Tindakan Kelas (PTK).Penelitian tindakan kelas merupakan proses pengkajian masalah pembelajaran didalam kelas melalui refleksi diri dalam upaya untuk menyelesaikan masalah tersebut dengan cara melakukan berbagai tindakan yang terencana dalam situasi nyata serta menganalisis setiap pengaruh dari perlakuan tersebut (Sanjaya, 2009: 26). Oleh sebab itu, dalam penelitian ini harapan untuk memecahkan masalah kurangnya kemampuan menulis puisi siswa dengan menerapkan teknik akrostik dengan memanfaatkan lingkungan sekolah. Penelitian tindakan kelas ini direncanakan terbagi menjadi 2 (dua) siklus dan dari setiap siklus dilaksanakan sesuai dengan perubahan yang ingin dicapai. Dimana setiap siklus terdiri dari 4 (empat) tahapan yaitu: perencanaan, pelaksanaan tindakan, observasi dan evaluasi. Sampel dari penelitian ini yaitu guru dan siswa kelas V semester II SDN I MIDANG yang berjumlah 35 siswa, 16 siswa laki-laki dan 19 siswa perempuan. Faktor yang diteliti yakni : faktor guru. Indikator keberhasilan penelitian terhadap kemampuan menulis puisi ini adalah apabila siswa memperoleh hasil individual dengan kriteria baik (65) berdasarkan kriteria ketuntasan minimal (KKM) dan mencapai $75 \%$ tingkat keberhasilan secara klasikal.

\section{HASIL PENELITIAN DAN PEMBAHASAN}

Penelitian tindakan kelas ini bertujuan untuk meningkatkan kemampuan siswa dalam menulis puisi melalui teknik akrostik dengan memanfaatkan lingkungan sekolah pada siswa kelas V/A semester II di SDN I Midang. Observasi dilakukan pada aktivitas guru, aktivitas siswa dalam merespon pembeljaran dan kemapuan menullis puisi.

Adapun rekapitulasi hasil penelitian dari sklus I dan II yang dapat diamati memuat hasil kemampuan menulis puisi, hasil observasi kemampuan guru dan hasil observasi respon siswa terhadap pembelajaran. Adapun perbandingan antara siklus I dengan siklus II dapat dilihat pada tabel 1 berikut: 
Tabel 1 Rekapitulasi Hasil Observasi dan Evaluasi dari Siklus I dan Siklus II

\begin{tabular}{|c|c|c|c|c|c|c|}
\multirow{3}{*}{ Siklus } & \multicolumn{2}{|c|}{ Aktivitas Guru } & \multicolumn{2}{c|}{ Aktivitas Siswa } & \multicolumn{2}{c|}{ Data Hasil Evaluasi } \\
\cline { 2 - 7 } & $\begin{array}{c}\text { Jumlah } \\
\text { Skor }\end{array}$ & Kriteria & $\begin{array}{c}\text { Jumlah } \\
\text { Skor }\end{array}$ & Kriteria & Rata-Rata & $\begin{array}{c}\text { Ketuntasan } \\
\text { Klasikal }\end{array}$ \\
\hline I & 40 & Baik & 40 & Baik & 70,9 & $74 \%$ \\
\hline II & 43 & Baik & 42 & Baik & 75,4 & $89 \%$ \\
\hline Peningkatan & 3 & & 2 & & 4,5 & $15 \%$ \\
\hline
\end{tabular}

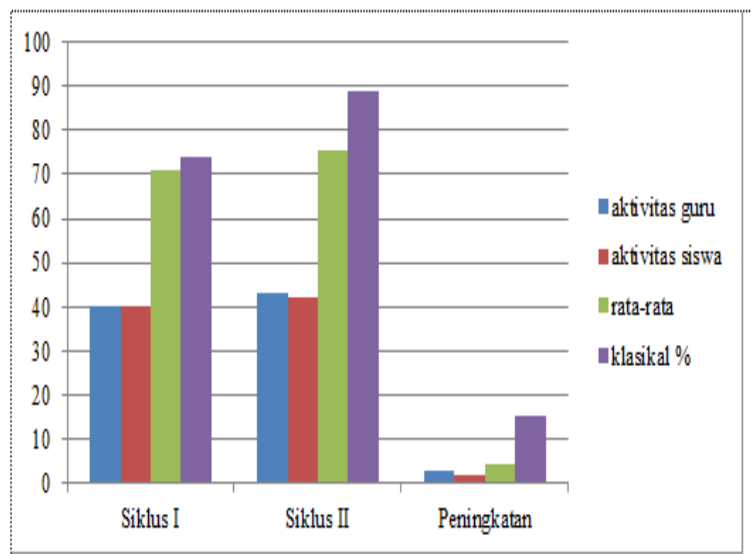

Grafik 1. Rekapitulasi Hasil Penelitian dari Siklus I dan Siklus II

Berdasarkan tabel diatas dapat diketahui bahwa skor dari siklus I ke siklus II baik pada kemampuan guru, respon siswa terhadap pembelajaran dan hasil evaluasi kemampuan menulis puisi siswa mengalami peningkatan yang dapat diuraikan sebagai berikut: (a) jumlah skor aktivitas guru dalam pembelajaran pada siklus I dari 40 meningkat pada siklus II menjadi 43; (b) jumlah skor aktivitas siwa dalam merespon pelaksanaan proses pembelajaran siklus I dari 40 meningkat menjadi 42 pada siklus II; (c) nilai rata-rata kemampuan menulis puisi siswa pada siklus I dari 70,9 meningkat menjadi 75,4 pada siklus II; (d) kriteria ketuntasan klasikal meningkat dari $74 \%$ menjadi $89 \%$ setelah pembelajaran pada siklus II.

Dari pembahasan diatas menunjukkan bahwa kinerja guru, respon siswa terhadap pembelajaran dan hasil tes kemampuan menulis puisi siswa mengalami
peningkatan.Peningkatan ini terjadi karena adanya perbaikan-perbaikan yang dilakukan pada siklus II terhadap kendala-kendala yang terjadi pada siklus I, dimana guru sudah mampu mengkondisikan kelas dengan baik dan memberikan penjelasan yang lebih mendalam mengenai teknik akrostik sehingga siswa tidak bingung lagi dengan langkahlangkah dalam membuat puisi akrostik. Selain itu, guru melakukan pembenahan terhadap media yang digunakan untuk membangkitkan motivasi siswa yaitu dengan membuat tekateki silang yang lebih menarik sehingga siswa termotivasi untuk mengeluarkan ide-ide yang ada dalam pikirannya serta memberikan reward berupa hadiah alat tulis kepada siswa yang berani membacakan puisinya didepan kelas, dengan demikian semua siswa termotivasi untuk aktif dalam kegiatan pembelajaran. Guru lebih aktif dalam memberikan bimbingan pada tahap penulisan puisi sehingga tidak ada siswa yang berkeliaran bertanya pada temannya dan siswa tidak merasa kesulitan dalam mencari kata-kata yang tepat untuk menulis puisinya, dan tidak kalah penting adalah penggunaan metode pembelajaran yang variatif sehingga berimplikasi pada peningkatan kemampuan menulis puisi siswa.

Peningkatan hasil kemampuan menulis puisi siswa tidak terlepas dari treatment yang diberikan oleh guru selama pembelajaran berlangsung. Menulis puisi dengan teknik akrostik memberikan kemudahan bagi siswa untuk menyusun katakata dalam puisinya, dimana menurut Noer Tugiman (dalam Suminto, 2009:56) mengatakan bahwa akrostik adalah salah satu bentuk puisi yang setiap huruf awalnya merupakan susunan nama atau kata. Dengan demikian, penggunaan teknik akrostik dalam menyusun puisi dapat memberikan kemudahan dan menyenangkan bagi siswa karena huruf awal dari setiap baitnya merupakan susunan kata yang berkesan untuk mereka yang disertai dengan pewarnaan pada 
huruf awal tiap-tiap barisnya sehingga membuat siswa semangat menulis puisi.

Selain itu, pemanfaatan lingkungan sekolah melalui proses pengamatan juga memberikan dampak yang signifikan dalam meningkatkan hasil kemampuan menulis puisi siswa karena melalui proses tersebut siswa dapat menemukan kosakata yang tepat untuk menulis kalimat pada puisinya. Hal ini sejalan dengan pendapat Kusuma (dalam Abdiyati, 2011:16) mengemukakan bahwa lingkungan adalah segala sesuatu yang ada di sekitar manusia yang mempengaruhi perkembangan manusia baik langsung maupun tidak langsung, lingkungan yang dimaksud dalam hal ini adalah lingkungan sekolah. Lingkungan sekolah yang digunakan dalam pembelajaran puisi adalah sarana nyata yaitu dimana guru menunjukkan sebuah benda apa saja yang ada di sekitar sekolah, selanjutnya siswa dibimbing untuk menemukan diksi berdasarkan lingkungan sekolah dengan memanfaatkan inderanya dan huruf-huruf awal yang telah diperolehnya dari penggunaan teknik akrostik, setelah itu merangkainya menjadi puisi. Ini berarti, keberhasilan dalam belajar bukan sematamata harus diperoleh dari guru saja, melainkan dapat juga diperoleh dari lingkungan sekitar khususnya lingkungan sekolah.Dalam hal ini guru bertindak sebagai fasilitator.

Meningkatnya

kemampuan menulis puisi merupakan sebuah capaian hasil belajar.Penerapan teknik akrostik dengan memanfaatkan lingkungan sekolah merupakan sebuah upaya atau perlakuan yang diberikan kepada siswa untuk mengasimilasikan stimulus-stimulus baru yang ada sehingga menjadi sebuah capaian hasil belajar berupa meningkatnya kemampuan menulis puisi siswa.

Menurut teori kognitif mengatakan bahwa Belajar merupakan aktivitas yang melibatkan proses berfikir yang sangat kompleks. Proses belajar terjadi antara lain mencakup pengaturan stimulus yang diterima dan menyesuaikannya dengan strukutur kognitif yang telah dimiliki dan terbentuk dalam pikiran seseorang berdasarkan pemahaman dan pengalaman-pengalaman sebelumnya (Budiningsih, 2004:35). Berdasarkan uraian diatas terlihat bahwa pembelajaran menulis puisi merupakan suatu kegiatan atau pelajaran yang telah diberikan pada kelas sebelumnya, namun penerapan yang baru yaitu melalui teknik akrostik dengan memanfaatkan lingkungan sekolah dapat memberikan pengetahuan yang baru kepada siswa untuk dapat meningkatkan kemampuan menulis puisi.

Dengan demikian, pada siklus berikutnya dapat dihentikan serta dapat ditarik kesimpulan bahwa penggunaan teknik akrostik dengan memanfaatkan lingkungan sekolah dapat meningkatkan kemampuan menulis puisi siswa kelas V SDN I Midang tahun ajaran 2018/.2019.

\section{KESIMPULAN}

Penggunaan teknik akrostik dengan memanfaatkan lingkungan sekolah dapat meningkatkan kemampuan menulis puisi siswa kelas V/A,di SDN I Midang tahun ajaran 2018/2019. Penggunaan teknik akrostik dengan memanfaatkan lingkungan sekolah dapat meningkatkan aktivitas guru dalam pembelajaran di kelas. Penggunaan teknik akrostik dengan memanfaatkan lingkungan sekolah dapat meningkatkan aktivitas siswa dalam merespon pembelajaran.

\section{DAFTAR PUSTAKA}

Abdiyati. 2011. "Meningkatkan Kemampuan Menulis Puisi Dengan Menggunakan Media Lingkungan Sekolah Pada Siswa Kelas V SDN 1 Rempung Lombok TimurTahun Ajaran 2010/2011”. Mataram: FKIP UniversitasMataram

Akhadiah, Sabarti, dkk. 1997. Menulis. Jakarta: Depdikbud

Aminuddin. 2011. Pengantar Apresiasi Karya Sastra. Bandung: Sinar Baru Algesindo 
Arifin, Zainal. 2009. Evaluasi Pembelajaran. Bandung: PT Remaja Rosdakarya

Budiningsih, Asri. 2004. Belajar dan Pembelajaran. Yogyakarta: Rineka Cipta

Depdiknas.2006. Kurikulum Tingkat Satuan Pendidikan Sekolah Dasar/Madrasah Ibtidaiyah. Jakarta: Depdiknas

Isnaini, LMY., Hananingsih, W. 2018. Persepsi dan Motivasi Mahasiswa Pada UKM Bola Basket di Universitas Nahdlatul Ulama NTB. JISIP (Jurnal Ilmu Sosial dan Pendidikan) 2 (1).

Isnaini, LMY. 2012. Pembinaan Olahraga Dalam Pembentukan Karakter. Surabaya. 9786027508 75-0 12 (978 6027508 75-0), 12 vol.

Nurkancana dan Sunartana. 1990. Evaluasi Hasil Belajar. Surabaya: Usaha Nasional

Saini KM. 2013. Pengertian Menulis Puisi dan Langkah-Langkah Menulsi Puisi http://inichuwi.blogspot.com, (diakses tanggal 24 Oktober 2018)

Sanjaya, Wina. 2009. Penelitian Tindakan Kelas. Jakarta: Kencana

Santani, Piya. 2010. "Peningkatan Kemampuan Menulis Puisi Dengan Media Lingkungan Siswa Kelas X C SMA Muhammadiyah Mataram Tahun Pembelajaran 2009/2010". Mataram: FKIP Universitas Mataram

Suminto, dkk. 2009. Cara MenulisKreatif. Yogyakarta: Pustaka Pelajar

Suriamiharja, Agus, dkk. 1997. Petunjuk Praktis Menulis. Jakarta: Depdikbud

Suyatno.2012. Teknik Pembelajaran Bahasa dan Sastra.Surabaya: SIC

Tarigan, H.G. 2011.Prinsip-Prinsip Dasar Sastra.Bandung: Angkasa

Tim penyusun. 2010. Pedoman Penulisan Skripsi program S1 PGSD DAN PAUD. Mataram: FKIP Universitas Mataram 